Alpi Subahan ${ }^{1}$ Dini Xena Dista ${ }^{2}$ Ramdhan Witarsa ${ }^{3}$

\section{KAJIAN LITERATUR TENTANG KEBIJAKAN PENDIDIKAN DASAR DI MASA PANDEMI DAN DAMPAKNYA TERHADAP PEMBELAJARAN}

\begin{abstract}
Abstrak
Penelitian ini bertujuan untuk mendeskripsikan kajian literatur tentang kebijakan pendidikan dasar di masa pandemi dan dampaknya terhadap pembelajaran. Metode penelitian ini menggunakan metode penelitian kualitatif dengan pendekatan kajian literatur. Tahapan penelitian dilakukan mulai dari pengumpulan artikel, reduksi artikel, display artikel, pembahasan, dan kesimpulan. Sumber data penelitian berupa artikel-artikel jurnal nasional dalam 1 tahun terakhir (2019-2020). Hasil penelitian menunjukkan bahwa dari 15 artikel didapatkan 3 artikel yang sesuai dengan topik judul. Penerapan kebijakan pendidikan dasar di masa pandemi menimbulkan banyak kebijakan-kebijakan baru dan dampaknya sangat komplek dan berbeda di setiap daerah. Perlu peninjauan ulang tentang kebijakan yang diterapkan.
\end{abstract}

Kata Kunci: Kajian Literatur, Kebijakan, Pendidikan Dasar, Pandemi, Pembelajaran.

\begin{abstract}
This study aims to describe the literature review on elementary education policies during the pandemic and their impact on learning. This research method uses qualitative research methods with a literature review approach. The research stages were carried out starting from article collection, article reduction, article display, discussion, and conclusions. The source of research data is in the form of national journal articles in the last 1 year (2019-2020). The results showed that from 15 articles, there were 3 articles in accordance with the topic title. The implementation of elementary education policies during the pandemic has resulted in many new policies and the impact is very complex and different in each region. Needs a review of the policy applied.
\end{abstract}

Keywords: literature review, policy, elementary education, pandemic, learning,.

\title{
PENDAHULUAN
}

\footnotetext{
${ }^{1}$ Program Studi PGSD, Fakultas Ilmu Pendidikan, Universitas Pahlawan Tuanku Tambusai alpisubahan19@gmail.com

${ }^{2}$ Program Studi PGSD, Fakultas Ilmu Pendidikan, Universitas Pahlawan Tuanku Tambusai dini.bkn123@gmail.com

${ }^{3}$ Program Studi PGSD, Fakultas Ilmu Pendidikan, Universitas Pahlawan Tuanku Tambusai drdadan19@gmail.com
} 
Kebijakan berarti menangani masalah-masalah publik atau administrasi pemerintah. Pengertian kebijakan publik menurut (Saleh, A., 2020) adalah suatu daftar pilihan tindakan yang saling berhubungan, yang disusun oleh institusi atau pejabat pemerintah. Kebijakan adalah proses sosial dimana proses intelektual melekat didalamnya, bukan berarti bahwa efektivitas relatif dari proses intelektual tidak dapat ditingkatkan, atau bahwa proses sosial dapat diperbaiki, namun suatu proses sosial memerlukan waktu dalam penerapannya.

Penerapan kebijakan pendidikan dasar di masa pandemi ini tentu saja memberikan dampak bagi berlangsungnya pembelajaran. Pembelajaran yang selama ini berlangsung secara konvensional berupa tatap muka di ruang-ruang kelas sekolah harus beralih ke pembelajaran online menggunakan aplikasi-aplikasi yang mendukung. Kebijakan yang dikeluarkan oleh Kementerian Pendidikan dan Kebudayaan Republik Indonesia melalui SE nomor 4 tahun 2020 tentang pelaksanaan pendidikan masa darurat penyebaran Corona Virus Desease 2019 (Covid-19) dijelaskan bahwa penerapan dari kebijakan tersebut berdampak dalam proses pembelajaran di sekolah ((Sari, R., Tusyantari, N., \& Suswandari, 2021); (Hidayah, 2020); (Wiryanto, 2020)).

Berdasarkan pendapat beberapa ahli yang telah diungkapkan sebelumnya, dapat disimpulkan bahwa kebijakan pendidikan dasar di masa pandemi menimbulkan banyak dampak terhadap pembelajaran. Dampak tersebut tentu saja dirasakan oleh semua yang terkait dengan pembelajaran. Dampak tersebut dirasakan oleh siswa, guru, dan bahkan orang tua. Kendalakendala yang dihadapi berbeda untuk setiap daerahnya. Guru-guru di jenjang Sekolah Dasar (SD) yang kebanyakan sudah berusia senja, mengalami kendala dalam online karena tidak terbiasa dengan teknologi. Banyak guru yang gagap teknologi. Kendala lainnya adalah siswa di kelas rendah tidak memiliki perangkat android smartphone. Orang tua tidak memiliki android smartphone juga menjadi kendala tersendiri (Siahaan, 2020).

Dibalik kendala-kendala dan kesulitan dalam pembelajaran online, pembelajaran online sebenarnya memiliki beberapa keuntungan. Keuntungan-keuntungan pembelajaran online menurut (Dewi, W., A., 2020) sebagai berikut: memiliki keleluasaan waktu belajar, dapat belajar kapanpun dan dimanapun, dan menjawab tantangan akan ketersediaan sumber belajar yang variatif. Tujuan dikeluarkannya kebijakan pendidikan dasar ini tentu saja untuk mengatasi penyebaran covid-19. Dengan dilaksanakannya pembelajarn di rumah, maka angka kasus covid dapat ditekan. Penekanan ini ternyata menimbulkan masalah-masalah baru dalam dunia pendidikan, baik dari secara teori hingga ke masalah teknis.

Dengan memahami pengertian dan ciri-ciri pembelajaran online, siswa dituntut untuk segera bisa beradaptasi dalam waktu yang sangat singkat. Hal ini terpaksa dilakukan karena tidak ada pilihan lainnya. Apabila pelaksanaan pendidikan online ini diabaikan, maka bukan tidak mungkin kualitas pendidikan akan kembali merosot.

Dengan banyaknya artikel-artikel dan temuan-temuan lapangan yang menerapkan kebijakan pembelajaran online, maka peneliti merasa perlu untuk melakukan kajian literatur tentang kebijakan pendidikan dasar di masa pandemi dan dampaknya terhadap pembelajaran dengan tujuan sebagai berikut: Pertama, peneliti akan mengetahui kajian-kajian lain yang pernah dilakukan orang lain berkenaan dengan topik penelitian yang peneliti lakukan saat ini. Peneliti akan akrab dan memahami satu khazanah pengetahuan tentang topik penelitian yang dilakukan. Peneliti sedang membangun kredibilitas diri dalam khazanah pengetahuan yang menjadi topik penelitian. Satu kajian literatur memperlihatkan kepada pembaca tentang penguasaan peneliti tentang topik kajian yang peneliti lakukan. Makin baik dan makin lengkap 
penulisan kajian literatur, makin baik pula penghargaan orang terhadap peneliti sebagai penulis kajian tersebut (Tjahjono, H., 2018)

Kedua, kajian literatur akan menghubungkan kajian yang akan peneliti lakukan dengan wacana luas dalam literatur tentang topik tersebut. Peneliti akan menutupi jurang yang ada antara projek penelitian yang sedang peneliti kerjakan dengan dunia literatur secara umum, bahkan peneliti bisa memperluas kajian-kajian yang ada sebelumnya. Peneliti memahami alur perjalanan penelitian-penelitian sebelumnya tentang topik tersebut. Dengan pengetahuan tersebut, maka peneliti akan merancang bagaimana projek penelitian baru yang akan peneliti lakukan selanjutnya. Kajian literatur yang baik dapat menempatkan projek penelitian yang sedang dirancang ke dalam konteks bidang kajian yang terkait dengan khazanah umum, topik penelitian, dan daerah atau masyarakat penelitian.

Ketiga, menunjukkan kemampuan peneliti dalam mengintegrasikan dan meringkaskan apa yang sudah diketahui orang lain tentang bidang kajian yang sedang diteliti. Satu review merangkum dan mensintesakan keseluruhan hasil penelitian, mana hal yang sudah disepakati, mana yang masih dalam perdebatan, dan mana masih dalam perambahan, dan kira-kira ke arah mana topik penelitian ini akan berkembang pada masa yang akan datang. Keempat, dengan belajar dari orang lain peneliti dapat melahirkan pemikiran-pemikiran baru. Kajian literatur yang baik adalah mengenali aspek-aspek yang masih gelap dan memberi insight dan hipotesis baru bagi penelitian lanjutan (Marzali, 2016).

\section{METODE}

Metode yang digunakan dalam penelitian ini adalah kajian literatur. Kajian literatur merupakan langkah pertama dan penting dalam penyusunan sebuah rencana penelitian. Kajian literatur adalah satu penelusuran dan penelitian kepustakaan dengan membaca berbagai buku, jurnal, dan terbitan-terbitan lain yang berkaitan dengan topik penelitian, untuk menghasilkan satu tulisan berkenaan dengan satu topik atau isu tertentu (Marzali, 2016). Dalam kajian literatur untuk kepentingan menghasilkan sebuah tulisan ilmiah, seperti skripsi, tesis, dan disertasi, peneliti menjelajahi literatur-literatur yang berkaitan dengan topik dan masalah penelitiannya, tentang variabel-variabel penelitian, tentang teori-teori yang pernah digunakan, dan dihasilkan oleh peneliti lain yang berkaitan dengan topik penelitian yang akan peneliti teliti, tentang metode penelitian yang digunakan dalam kajian tersebut, dan seterusnya (Marzali, 2016).

Kajian literatur dilakukan atas kesadaran bahwa pengetahuan adalah bertambah terus menerus dan mengalami perkembangan, bahwa topik penelitian dan variabel-variabel penelitian yang akan peneliti lakukan sudah pernah dirambah peneliti lain sebelumnya, dan peneliti dapat belajar dari apa yang telah dilakukan peneliti-peneliti sebelumnya tersebut. Jadi, peneliti bukanlah peneliti yang pertama meneliti topik dan masalah tersebut. Ada dua tujuan utama dari kajian literatur. Pertama, kajian literatur yang dilakukan dengan tujuan untuk menulis sebuah artikel untuk memperkenalkan kajian-kajian baru dalam topik tertentu yang perlu diketahui oleh mereka yang bergiat dalam topik ilmu tersebut. Kajian ini sewaktu-waktu dapat diterbitkan untuk kepentingan umum. Contoh kajian-kajian semacam ini dapat dilihat misalnya dalam Annual Review of Anthropology, Annual Review of Sociology, dan sebagainya. Mereka yang baru menjadi peneliti pemula dalam topik tertentu dapat menggunakan terbitan annual review ini sebagai bacaan awal (Tjahjono, H., 2018).

Tujuan kedua dari kajian literatur adalah untuk kepentingan projek penelitian sendiri. Dalam hal ini, membuat kajian literatur adalah untuk memperkaya wawasan peneliti tentang suatu topik penelitian, menolong peneliti dalam memformulasikan masalah penelitian, dan 
menolong peneliti dalam menentukan teori-teori dan metode-metode yang tepat untuk digunakan dalam penelitian yang peneliti usung. Dengan memelajari kajian-kajian hasil penelitian orang lain, peneliti dapat menentukan apakah akan meniru, mengulangi, atau mengeritik satu kajian tertentu. Kajian-kajian hasil penelitian orang lain itu peneliti gunakan sebagai bahan pembanding bagi kajian peneliti sendiri. Dengan mengkritisi artikel-artikel hasil penelitian orang lain, peneliti lalu menciptakan sesuatu yang baru. Dalam artikel ini khusus akan dibincangkan kajian literatur untuk kepentingan penelitian sendiri, khususnya bagi mahasiswa yang belajar menulis suatu artikel ilmiah (Marzali, 2016).

Berdasarkan paparan tersebut, maka peneliti menggunakan kajian literatur dengan menganalisis artikel-artikel ilmiah dari jurnal nasional yang terbit pada tahun 2019 sampai dengan 2020 sebagai metode penelitian agar terlaksananya penelitian yang dimaksud. Tahapantahapan yang digunakan pada kajian literatur dapat dilihat pada Gambar 1 berikut:

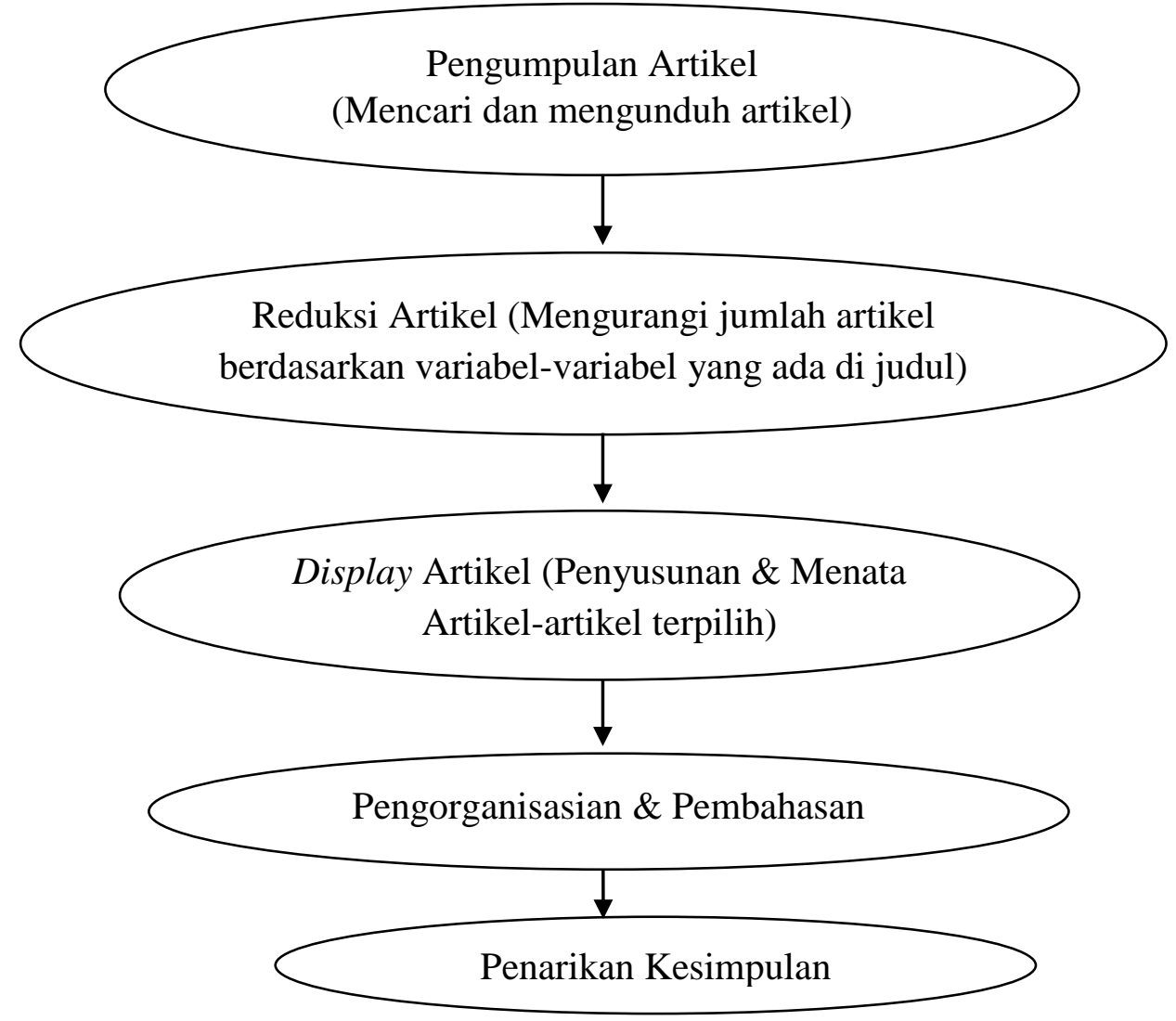

Gambar 1. Tahapan-Tahapan Kajian Literatur

(Sumber: (Marzali, 2016))

1) Pengumpulan Artikel (Mencari dan mengunduh artikel).

Pada tahap pengumpulan artikel ini dilakukan dengan cara mencari dan mengunduh artikelartikel melalui google sholar dengan cara mengetikan kata-kata kunci yang berkaitan dengan topik atau judul penelitian. Dalam hal ini, kata-kata kuncinya adalah kebijakan pendidikan dasar di masa pandemi dan dampaknya terhadap pembelajaran.

2) Reduksi Artikel (Mengurangi jumlah artikel berdasarkan variabel-variabel yang ada di judul). 
Reduksi artikel berarti merangkum, memilih hal-hal yang pokok, memfokuskan pada halhal yang penting, dicari tema dan polanya serta membuang yang tidak perlu. Dengan demikian, artikel yang telah direduksi akan memberikan gambaran yang jelas dan mempermudah peneliti untuk melakukan pengumpulan data selanjutnya dan mencarinya apabila diperlukan.

3) Display Artikel (Penyusunan dan menata artikel-artikel terpilih).

Setelah artikel direduksi, tahap selanjutnya adalah mendisplay atau penyajian artikel. Penyajian artikel ini dilakukan dalam bentuk tabel, uraian singkat, dan hubungan antar variabel.

4) Pengorganisasian dan Pembahasan

Pada tahap ini dilakukan pengorganisasian dan pembahasan berdasarkan jenis kajian literatur yang digunakan. Dalam hal ini, kajian literatur yang dipilih berupa kajian teori. Jenis kajian literatur berupa kajian teori ini adalah kajian khusus dimana penulis memaparkan beberapa teori atau konsep yang terpusat pada satu topik tertentu dan membandingkan teori atau konsep tersebut atas dasar asumsi-asumsi, konsistensi logik, dan lingkup eksplanasinya.

5) Penarikan Kesimpulan

Penarikan kesimpulan dilakukan berdasarkan hasil pengorganisasian dan pembahasan yang telah dilakukan sebelumnya.

\section{HASIL DAN PEMBAHASAN}

Pada tahap awal pengumpulan artikel berdasarkan variabel-variabel yang terdapat pada judul, yaitu kebijakan pendidikan dasar di masa pandemi dan dampaknya terhadap pembelajaran, dari 15 artikel didapatkan 3 artikel yang sesuai dengan topik judul. Pada tahap reduksi artikel, terdapat 12 artikel yang harus dibuang dikarenakan terdapat satu variabel yang tidak sesuai dengan topik judul. Ke-12 artikel tersebut dibuang dengan alasan salah satu variabel yang ada pada topik judul tidak ada. Misalnya, ada artikel yang hanya membahas pendidikan dasar saja, namun tidak membahas kebijakan-kebijakan yang dilakukan.

Artikel-artikel kebijakan pendidikan dasar di masa pendemi dan dampaknya terhadap pembelajaran yang berjumlah 3 artikel didisplay artikelnya pada Tabel 1 berikut:

Tabel 1. Display Artikel

\begin{tabular}{|c|c|c|l|l|l|c|}
\hline No. & $\begin{array}{c}\text { Nama Penulis } \\
\text { Artikel }\end{array}$ & $\begin{array}{c}\text { Tahun } \\
\text { Terbit }\end{array}$ & \multicolumn{1}{|c|}{ Judul Artikel } & Nama Jurnal & $\begin{array}{l}\text { Volume } \\
\text { Nomor }\end{array}$ & $\begin{array}{c}\text { Jumlah } \\
\text { Halaman }\end{array}$ \\
\hline 1 & $\begin{array}{l}\text { 1. } \begin{array}{l}\text { Ahmad } \\
\text { Muzawir } \\
\text { Saleh } \\
(1 \text { orang) }\end{array} \\
\end{array}$ & 2019 & $\begin{array}{l}\text { Problematika } \\
\text { Kebijakan } \\
\text { Pendidikan di } \\
\text { Tengah Pandemi } \\
\text { dan Dampaknya } \\
\text { terhadap Proses } \\
\text { Pembelajaran di } \\
\text { Indonesia }\end{array}$ & $\begin{array}{l}\text { Jurnal } \\
\text { Pendidikan }\end{array}$ & $\begin{array}{l}\text { Vol. 03, } \\
\text { No. 11. }\end{array}$ & $\begin{array}{c}5 \\
\text { Halaman } \\
\text { (Hal. 1-5) }\end{array}$ \\
& $\begin{array}{l}\text { 1. Ahmad } \\
\text { Fikri Sabiq } \\
\text { Muhamma } \\
\text { d }\end{array}$ & 2020 & $\begin{array}{l}\text { Dukungan } \\
\text { Pemerintah Desa } \\
\text { terhadap Problem } \\
\text { Pendidikan di Masa }\end{array}$ & $\begin{array}{l}\text { Jurnal } \\
\text { Khazanah } \\
\text { Pendidikan } \\
\text { Islam }\end{array}$ & $\begin{array}{l}\text { Vol. 2, } \\
\text { No. 3. }\end{array}$ & $\begin{array}{c}\text { Halaman } \\
\text { (Hal. } \\
107-113)\end{array}$ \\
\hline 2
\end{tabular}




\begin{tabular}{|c|c|c|c|c|c|c|}
\hline No. & $\begin{array}{c}\text { Nama Penulis } \\
\text { Artikel }\end{array}$ & $\begin{array}{l}\text { Tahun } \\
\text { Terbit }\end{array}$ & Judul Artikel & Nama Jurnal & $\begin{array}{l}\text { Volume } \\
\text { Nomor }\end{array}$ & $\begin{array}{l}\text { Jumlah } \\
\text { Halaman }\end{array}$ \\
\hline & $\begin{array}{l}\text { Sa'dullah } \\
\text { (2 Orang) }\end{array}$ & & Pandemi Covid-19 & & & \\
\hline 3 & \begin{tabular}{|l} 
1. Laila Nur \\
Alfiah \\
2. Deni Ainur \\
Rokhim \\
3. Intan Ayu \\
Idha \\
(3 orang)
\end{tabular} & 2020 & $\begin{array}{l}\text { Analisis Dampak } \\
\text { Anjuran } \\
\text { Pemerintah } \\
\text { terhadap Belajar di } \\
\text { Rumah bagi Pelaku } \\
\text { Pendidikan }\end{array}$ & $\begin{array}{l}\text { JAMP: } \\
\text { Jurnal } \\
\text { Adminitrasi } \\
\text { dan } \\
\text { Manajemen } \\
\text { Pendidikan }\end{array}$ & $\begin{array}{l}\text { Vol. 03, } \\
\text { No. 03. }\end{array}$ & $\begin{array}{c}8 \\
\text { Halaman } \\
\text { (Hal. 216 } \\
-223)\end{array}$ \\
\hline
\end{tabular}

Pada artikel satu yang ditulis oleh (Saleh, A., 2020) dengan judul Problematika Kebijakan Pendidikan di Tengah Pandemi dan Dampaknya terhadap Proses Pembelajaran di Indonesia mengungkapkan bahwa belajar dari rumah yang ditetapkan melalui kebijakan yang dikeluarkan oleh Kementerian Pendidikan dan Kebudayaan Republik Indonesia melalui SE nomor 4 tahun 2020 tentang pelaksanaan pendidikan masa darurat penyebaran Corona Virus Desease 2019 (Covid-19) dijelaskan bahwa penerapan dari kebijakan tersebut berdampak dalam proses pembelajaran yang ada di sekolah, terutama bagi siswa, guru, orang tua dan atau keluarga siswa. Ternyata hal ini bukan hanya dirasakan oleh siswa saja, ternyata mahasiswapun mengalami hal yang sama. Hal ini diketahui dari hasil penelitian yang dilakukan oleh (Argaheni, N., 2020) yang mengungkapkan bahwa pembelajaran online memiliki beberapa dampak terhadap mahasiswa sebagai berikut: (1) pembelajaran online masih membingungkan mahasiswa; (2) mahasiswa menjadi pasif, kurang kreatif, dan produktif; (3) penumpukan informasi/ konsep pada mahasiswa kurang bermanfaat; (4) mahasiswa mengalami stress; dan (5) peningkatan kemampuan literasi bahasa mahasiswa.

Proses pembelajaran sebagai sesuatu yang dialami siswa di sekolah sendiri merupakan alat kebijakan publik terbaik sebagai upaya peningkatan pengetahuan dan skills. Hal yang kemudian juga telah tertanam dalam diri sebagian besar siswa adalah sekolah menjadi tempat yang menyenangkan sebagai wahana bermain, berinteraksi, dan membangun hubungan serta kesadaran sosial. Sekolah pula menjadi pusat interaksi antara guru dengan siswa dalam meningkatkan pengetahuan, keterampilan, penanaman sikap, dan karakter. Dengan kebijakan yang mengharuskan belajar di rumah, maka hal tersebut secara terpaksa dan tiba-tiba harus terhenti. Hal ini menyebabkan banyak siswa menjadi bingung dan tanpa arah. Peningkatan keterampilan dan skills terhenti sesaat diakibatkan kurang maksimalnya kelerlibatan siswa dalam pembelajaran. Hal ini sejalan dengan hasil penelitian yang dilakukan oleh (Anugrahana, 2020) yang menjelaskan bahwa kelemahan dalam pembelajaran online adalah kurang maksimalnya keterlibatan siswa. Maksud dari kurangnya keterlibatan siswa dalam mengikuti pembelajaran online adalah siswa tidak secara penuh mengikuti dari awal pembelajaran sampai akhir pembelajaran. Hasil penelitian menunjukkan bahwa hanya 50\% siswa yang aktif terlibat secara penuh, $33 \%$ siswa yang terlibat aktif, dan $17 \%$ lainnya siswa yang kurang aktif dan kurang berpartisipasi dalam pembelajaran online.

Kebijakan yang dikeluarkan Kementerian tersebut dilakukan sebagai upaya untuk menyelamatkan siswa dari bahaya virus, tetapi justru menimbulkan beberapa dampak khususnya pada siswa, guru, dan orang tua. Siswa sendiri merasa terpaksa belajar dari rumah 
yang sebenarnya tidak memiliki fasilitas yang memadai, dengan demikian maka pembelajaran menjadi terhambat. Hal ini dikarenakan tidak tersedianya fasilitas pendukung yang disiapkan sebelumnya di rumah. Proses adaptasi pembelajaranpun awalnya berlangsung lambat, siswa yang tadinya cenderung berinteraksi langsung dalam pembelajaran memerlukan berbagai macam adaptasi belajar serta memahami pembelajaran yang dimodelkan dalam jaringan online, sehingga kebijakan yang diberikan bisa saja menimbulkan mandeknya pemahaman siswa terhadap pembelajaran. Mengigat bahwa perubahan ke pembelajaran online secara tidak langsung berpengaruh terhadap daya serap siswa. Hal ini juga ditunjukkan dengan hasil penelitian yang dilakukan oleh (Mastura \& Santaria, 2020) yang mengungkapkan bahwa siswa kesulitan mengikuti pembelajaran online dikarenakan kurangnya akses internet, siswa mengungkapkan kadang jaringan bagus dan juga kurang bagus, begitupun dengan kuota data yang digunakan siswa yang mengganggap suatu pemborosan.

Pada artikel dua yang ditulis oleh (Sabiq, A. \& Sa'dullah, 2020) dengan judul Dukungan Pemerintah Desa terhadap Problem Pendidikan di Masa Pandemi Covid-19 mengungkapkan bahwa selain kebijakan yang dibuat oleh Kementerian Pendidikan dan Kebudayaan Republik Indonesia, maka perlu didukung dengan kebijakan lainnya agar implementasi pendidikan dasar di lapangan dapat terlaksana dengan baik. Dukungan pemerintah desa terhadap dunia pendidikan yang saat ini dilakukan adalah kebijakan pengadaan jaringan internet. Untuk siswa, fasilitas jaringan internet ini dilakukan dengan cara pemberian akun gratis yang diberikan selama jam belajar. Fasilitas ini bisa digunakan oleh siswa untuk menunjang pembelajaran jarak jauh. Untuk guru, mereka difasilitasi adanya jaringan internet gratis 24 jam selama masa pandemi ini. Fasilitas ini diharapan bisa mengkoordinir siswa dan mudah mencari bahan ajar dari internet. Pengadaan fasilitas jaringan internet ini juga menemui kendala dalam praktiknya. Hal ini juga diungkapkan dengan hasil penelitian yang dilakukan oleh (Safitri, N., Zulfa, Cristanti, Wulandari, P., \& Islami, E., 2020) yang menjelaskan bahwa penambahan biaya pembelian kuota internet bertambah dan ini memberatkan orang tua, teknologi online yang memerlukan koneksi jaringan ke internet dan kuota menambah beban pengeluaran orang tua dan tidak semua orang tua memiliki ponsel yang mendukung proses pembelajaran secara online.

Kebijakan yang diterapkan oleh pemerintah desa merupakan satu langkah alternatif yang memberikan solusi atas masalah-masalah yang dihadapi oleh guru, siswa, dan orang tua selama pembelajaran jarak jauh. Dengan adanya jaringan internet gratis ini, guru bisa lebih mudah untuk mencari sumber pembelajaran dan memberikan materi serta penugasan kepada siswa. Siswa selaku objek utama dari pendidikan juga bisa dengan mudah bisa mengakses materi pelajaran yang diberikan oleh guru. Orang tua selaku orang yang secara langsung mendampingi siswa belajar selama di rumah ini juga dimudahkan. Hal ini sejalan juga dengan hasil penelitian yang dilakukan oleh (Rokhani, C., T., 2020) yang mengungkapkan bahwa belajar dan bekerja di rumah memang mudah, hal ini ditunjukkan dengan data $87,5 \%$ siswa dan guru lebih aman bekerja dan belajar di rumah karena dapat terhindar dari penyebaran COVID-19. Belajar dan bekerja di rumah juga mengurangi biaya transportasi dari rumah ke sekolah sebanyak $75 \%$.

Dunia internet juga tidak lepas dari sisi positif dan negatif didalamnya. Hal ini juga harus diwaspadai oleh pemangku kebijakan yang memilih internet sebagai alternatif solusi. Pemerintah desa mengantisipasi hal tersebut, yaitu dengan memberikan proteksi di server, pembatasan waktu penggunaan, dan pendampingan dari orang yang lebih dewasa ketika siswa melaksanakan pembelajaran. Termasuk juga antisipasi yang mengarah kepada kecanduan penggunaan smartphone dengan adanya batasan waktu. Dari berbagai rangkaian kebijakan oleh pemerintah desa, peneliti menyatakan bahwa kebijakan program ini bisa menjadi role model untuk diterapkan di daerah lain sebagai alternatif solusi terkait kendala-kendala dalam pembelajaran jarak jauh. Hal ini sejalan dengan hasil penelitian yang dilakukan oleh (Santosa, A., 2020) yang mengungkapkan bahwa perlu dukungan semua pihak untuk mengatasi disparitas pendidikan di Indonesia, dimana peran dan tanggung jawab pendidikan di Indonesia bukan 
hanya menjadi tanggung jawab Pemerintah Pusat semata, melainkan tanggung jawab Pemerintah Daerah, dan masyarakat umum.

Pada artikel tiga yang ditulis oleh (Alfiah, L., Rokhim, D., \& Wulandari, I., A., 2020) dengan judul Analisis Dampak Anjuran Pemerintah terhadap Belajar di Rumah bagi Pelaku Pendidikan dijelaskan bahwa dampak yang terjadi pada guru menunjukkan bahwa penerapan pembelajaran online mengakibatkan proses pembelajaran terhambat karena beberapa guru senior tidak mampu mengaplikasikan internet atau gagap teknologi. Perlu adanya pendampingan dan pelatihan pembelajaran online. Selama pandemi Covid-19 proses pembelajaran berlangsung secara searah, sehingga siswa dan guru dapat menggunakan fasilitas paltform e-learning seperti Ruang Guru, Google Clasroom, Google Meet, dan Zoom.

Dampak bagi siswa adalah pembelajaran online menghambat proses mengingat materi karena pembelajaran berlangsung hanya sekedar chatting. Terdapat beberapa siswa yang tidak mampu menggali sendiri pengetahuannya, sehingga guru harus memiliki keterampilan menjelaskan agar mampu memfasilitasi pengetahuan siswa. Hal ini juga ditunjukkan dengan hasil penelitian yang dilakukan oleh (Aji, R., H., 2020) yang memaparkan bahwa dampak covid-19 sangat mempengaruhi pendidikan di Indonesia, terutama dalam hal pembelajaran.

\section{UCAPAN TERIMA KASIH}

Tim peneliti mengucapkan terima kasih kepada Universitas Pahlawan Tuanku Tambusai dan Program Studi Pendidikan Guru Sekolah Dasar yang telah memberi dukungan terhadap terlaksananya penelitian ini. Tim peneliti juga mengucapkan terima kasih kepada Pengelola Jurnal Review Pendidikan dan Pengajaran (JRPP) yang telah memberi review dan masukan atas terbitnya artikel ini.

\section{SIMPULAN}

Berdasarkan hasil kajian literatur tentang kebijakan pendidikan dasar di masa pandemi dan dampaknya terhadap pembelajaran dapat disimpukan bahwa dari 15 artikel yang terbit pada tahun 2019-2020 didapatkan 3 artikel yang sesuai dengan variabel-variabel yang ada dijudul. Penerapan kebijakan pendidikan dasar di masa pandemi dan dampaknya terhadap pembelajaran dapat dikatakan menimbulkan banyak permasalahan pada awalnya, namun secara perlahan permasalahan-permasalahan tersebut bisa teratasi. Penerapan kebijakan pendidikan dasar di masa pandemi perlu didukung dengan kelengkapan fasilitas agar dampak terhadap pembelajaran bisa diatasi dengan efektif dan efisien.

\section{DAFTAR PUSTAKA}

Aji, R., H., S. (2020). Dampak Covid-19 pada Pendidikan di Indonesia: Sekolah, Keterampilan, dan Proses Pembelajaran. SALAM: Jurnal Sosial Dan Budaya Syar-I, 7(5), 395-402. https://doi.org/10.15408/sjsbs.v7i5.15314

Alfiah, L., N., Rokhim, D., A., \& Wulandari, I., A., I. (2020). Analisis Dampak Anjuran Pemerintah Terhadap Belajar Di Rumah Bagi Pelaku Pendidikan. Jurnal Administrasi Dan Manajemen Pendidikan, 3(3), 216-223.

Anugrahana, A. (2020). Hambatan, Solusi dan Harapan: Pembelajaran Daring Selama Masa Pandemi Covid-19 Oleh Guru Sekolah Dasar. Scholaria: Jurnal Pendidikan Dan Kebudayaan, 10(3), 282-289. https://doi.org/10.24246/j.js.2020.v10.i3.p282-289

Argaheni, N., B. (2020). Sistematik Review: Dampak Perkuliahan Daring Saat Pandemi COVID-19 Terhadap Mahasiswa Indonesia. PLACENTUM: Jurnal Ilmiah Kesehatan Dan Aplikasinya, 8(2), 99-108. https://doi.org/10.20961/placentum.v8i2.43008 
Dewi, W., A., F. (2020). Dampak COVID-19 terhadap Implementasi Pembelajaran Daring di Sekolah Dasar. Edukatif: Jurnal Ilmu Pendidikan, 2(1), 55-61. https://doi.org/10.31004/edukatif.v2i1.89

Hidayah, N. (2020). Dampak Sistem Pembelajaran Daring Terhadap Kegiatan Belajar Mengajar Pada Masa Pandemi Covid 19 Di SDN 3 Sriminosari. As-Salam: Jurnal Studi Hukum Islam \& Pendidikan, 9(2), 189-206. https://doi.org/10.51226/assalam.v9i2.180

Marzali, A. (2016). Menulis Kajian Literatur. Jurnal Etnosia, 1(2), 27-36.

Mastura, \& Santaria, R. (2020). Dampak Pandemi Covid-19 terhadap Proses Pengajaran bagi Guru dan Siswa. Jurnal Studi Guru Dan Pembelajaran, 3(2), 289-295.

Rokhani, C., T., S. (2020). Pengaruh Work From Home (WFH) Terhadap Kinerja Guru SD Negeri Dengkek 01 Pati Selama Masa Pandemi Covid-19. EduPsyCouns: Journal of Education, Psychology and Counseling, 2(1), 424-437. Retrieved from https://ummaspul.e-journal.id/Edupsycouns/article/view/500

Sabiq, A., F., \& Sa'dullah, M. (2020). Dukungan Pemerintah Desa Terhadap Problem Pendidikan Di Masa Pandemi Covid-19. Jurnal Khazanah Pendidikan Islam, 2(3), 107113. https://doi.org/10.15575/kp.v2i3.

Safitri, N., G., Zulfa, A., Cristanti, A., Wulandari, P., R., \& Islami, E., N. (2020). Dampak Pandemi Covid-19 terhadap Penerapan Pembelajaran Daring di Sekolah Dasar. Journal of Chemical Information and Modeling, 53(9), 1-7.

Saleh, A., M. (2020). Problematika Kebijakan Pendidikan Di Tengah Pandemi Dan Dampaknya Terhadap Proses Pembelajaran Di Indonesia. Jurnal Pendidikan, 2(2), 24-28.

Santosa, A., B. (2020). Potret Pendidikan di Tahun Pandemi : Dampak COVID-19 Terhadap Disparitas Pendidikan di Indonesia. CSIS Commentaries, 1(1), 1-5.

Sari, R., P., Tusyantari, N., B., \& Suswandari, M. (2021). Dampak Pembelajaran Daring Bagi Siswa Sekolah Dasar Selama Covid-19. Prima Magistra: Jurnal Ilmiah Kependidikan, 2(1), 9-15.

Siahaan, M. (2020). Dampak Pandemi Covid-19 Terhadap Dunia Pendidikan. Jurnal Kajian Ilmiah, 1(1), 73-80. https://doi.org/10.31599/jki.v1i1.265

Tjahjono, H., K. (2018). Studi Literatur Pengaruh Keadilan Distributif dan Keadilan Prosedural Pada Konsekuensinya Dengan Teknik Meta Analisis. Jurnal Psikologi, 35(1), 21-40.

Wiryanto. (2020). PROSES PEMBELAJARAN MATEMATIKA DI SEKOLAH DASAR DI TENGAH PANDEMI COVID-19. Jurnal Review Pendidikan Dasar: Jurnal Kajian Pendidikan Dan Hasil Penelitian, 6(2), 1-8. 